
Multidisciplinary
SCIENTIFIC JOURNAL
OF MARITIME RESEARCH

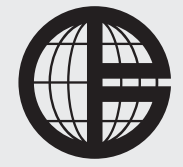
University of Rijeka
ULTY OF MARITIME STUDIES

\author{
Multidisciplinarni \\ znanstveni časopis \\ POMORSTVO
}

\title{
Determining the awareness and knowledge of officers towards ship energy efficiency measures
}

\author{
Elif Bal Beşikçi ${ }^{1}$, Murat Selçuk Solmaz², Irena Jurdana ${ }^{3}$ \\ ${ }^{1}$ Istanbul Technical University, Maritime Faculty, Department of Maritime Transportation Management Engineering, Postane Mahallesi, Manastır Yolu \\ Caddesi, No: 1, 34940 Tuzla/Istanbul, Turkey, e-mail: bale@itu.edu.tr (Corresponding author) \\ ${ }^{2}$ Piri Reis University, Maritime Faculty, Department of Maritime Transportation Management Engineering, Postane Mahallesi, Eflatun Sk. No: 8, 34940 \\ Tuzla/Istanbul, Turkey, e-mail: mssolmaz@pirireis.edu.tr \\ ${ }^{3}$ University of Rijeka, Faculty of Maritime Studies, Studentska 2, 51000 Rijeka, Croatia, e-mail: irena.jurdana@pfri.uniri.hr
}

\section{ABSTRACT}

Improving energy efficiency practices on ships is crucial for both economic and environmental purposes. Both technical and operational applications are made to increase energy efficiency on ships. The success of energy efficiency applications on ships depends on the effective work of seafarers. Therefore, awareness and knowledge about the energy efficiency of seafarers should be enough. The aim of the study is to determine the awareness and knowledge level of seafarers on energy efficiency on ships and to evaluate energy efficiency practices in maritime transportation companies from the perception of seafarers. In the study, the survey method was used. As a result of the survey, it was found that the knowledge level of the seafarers on ship energy efficiency was low, almost half of them did not receive energy efficiency training but they were informed about the importance of the issue. At the end of the study, it was evaluated that the awareness and knowledge level of officers should be increased in order to improve energy efficiency on ships and suggestions on this issue were determined.

\section{ARTICLE INFO}

Review article

Received 24 August 2021

Accepted 23 September 2021

\section{Key words:}

Ship energy efficiency

Seafarers

Ship officer

SEEMP

Awareness

Human factor

Ship management

\section{Introduction}

Maritime transportation provides safe, reliable, and cheap transportation that connects consumers with suppliers and raw materials worldwide. About 11 billion tons of cargo, which constitutes three-quarters of the goods of the world trade, is transported by sea and the number of vessels of 100 gross tons and above used in world maritime trade to carry this huge cargo is 98,140 (UNCTAD, 2020). Millions of tons of fuel consumed by the vessels cause both economic and environmental problems. Fuel, accounting for $50-70 \%$ of a ship's total operating cost (Rehmatulla \& Smith, 2015), is the most significant cost element of international transportation. Considering that the estimated fuel consumed annually in the 2007-2012 period is 201-272 million tons (International Maritime Organization [IMO], 2015), it is estimated that the money spent by the international maritime transportation on fuel increases by the US $\$ 80$ billion every year (Adland et al., 2018). In accordance with the "Third IMO GHG Study 2014", emissions generated by the fuel used in maritime transportation reached 938 million tons of carbon dioxide in 2012, which constitutes 2.6 percent of global emissions and if no action is taken, it is estimated that emissions will increase by 50 to 250 percent by 2050 (Li, Sun, Guo, $\mathrm{Du}, \& \mathrm{Li}, 2020)$. According to the report of the European Environment Agency (2013), emissions from maritime transportation must be monitored as it causes air pollution and climate change.

In order to fulfill the responsibility of the maritime sector in reducing greenhouse gas emissions, IMO has initiated studies on reducing the amount of carbon dioxide emitted from ships and made resolutions on a series of technical and operational measures from 2011. The energy-efficient use of ships was the focus of these technical and operational measures. Because IMO argued that if energy is used efficiently on ships, carbon emissions can be reduced (Banks, Turan, Incecik, Lazakis, \& Lu, 2012). The Energy Efficiency Design Index (EEDI) was made mandatory for new ships with an amendment to the International Convention for the Prevention of Pollution from Ships 
(MARPOL) Annex VI and entered into force on 01 January 2013. EEDI focuses on technical measures to ensure less fuel consumption and less carbon dioxide emissions. For this purpose, it requires the use of more energy-efficient equipment and machinery in new ships to be built. Ship Energy Efficiency Management Plan (SEEMP), which is made mandatory on ships, is a mandatory operational measure. SEEMP is a plan for a ship to use the ship in the most energy-efficient way with the least fuel consumption. IMO has also developed a guideline to assist in the preparation of this plan. In addition, SEEMP recommends using the Energy Efficiency Operational Indicator (EEOI). Through EEOI, maritime transportation companies can monitor the efficiency of their ships and fleets and take corrective measures, and the results of the actions taken to increase energy efficiency can be easily determined. In addition to these, IMO has made a fuel data collection system mandatory on ships. In this system, the distance traveled by ship, the time taken to cover this distance, and the amount of fuel consumed are recorded. (IMO, 2020a) In 2018, IMO adopted the initial IMO strategy on reduction of GHG emissions from ships. The aim of the strategy is to determine the actions and measures that will support the reduction of greenhouse gas emissions to be implemented by international maritime transportation. (IMO, 2018) As for IMO trainings, The International Convention on Standard of Training Certification and Watchkeeping for Seafarers (STCW) 1978, was updated in 2010, and "Marine Environmental Awareness Training" was added to each chapter (Banks et al., 2012). Additionally, in 2013, IMO developed a model course on Trainer's Training in ship energy efficiency with the World Maritime University (WMU) and in 2015, the course was updated and it was ensured that it also covers the latest developments in this field (IMO, 2020b).

The energy efficiency concept that IMO has brought to the maritime sector has made it necessary to make some regulations at both the company and the ship level. With these regulations, both technical and operational energy efficiency practices have been initiated on ships. Based on the IMO energy efficiency concept, practices are primarily handled and planned within the scope of a company policy. Both technical and operational practices require human involvement in selecting and implementing the best measures (Kitada \& Ölçer, 2015b). No matter how well the company plans the energy efficiency applications, if the seafarers who are responsible for implementing them and making operational decisions (Viktorelius \& Lundh, 2019) cannot implement this planning well enough, the established system cannot work efficiently and the desired results cannot be achieved. In other words, the human element (Kitada \& Ölçer, 2015a) is the focal point of ship energy efficiency applications.

Certainly, there are many internal and external stakeholders that directly or indirectly affect ship operations. For example, the cargo owner or the charterer can affect the navigation of the ship with clauses specified in the charter party. The company or ship operator to which the ship is affiliated can decide the ship's schedule and voyage plan by evaluating many factors such as maintenance, port of the next voyage. In addition, technical support providers who direct the ship to pass the storm zone to ensure safe navigation can be counted among these stakeholders. These and similar stakeholders directly or indirectly affect ship energy efficiency practices. (Banks et al., 2012) In addition, the human element contains many factors and behaviors such as fatigue, stress, health, non-technical skills, situation awareness, decision making and cognitive demands, communication, language and cultural diversity, and teamwork (Kitada \& Ölçer, 2015a). These guide the daily behavior of humans. It is inevitable that these factors and behaviors also affect the efficiency of the practices in ship energy efficiency applications, which are included in the daily working period of the seafarers. In the study, among these factors and behaviors, "awareness and knowledge" were selected and evaluated within the scope of ship energy efficiency practices of seafarers.

Effective implementation of energy efficiency practices onboard depends on the awareness and knowledge of seafarers who are in the position of executives in energy efficiency applications on ships (Banks et al., 2012; Kitada \& Ölçer, 2015a). Without awareness, knowledge, and skills cannot be utilized, because the focus is required to use learned knowledge, and focus can be achieved through awareness (Banks, Lazakis, Turan, \& Incecik, 2011). In addition, knowledge and motivation are built on awareness (Banks et al., 2012). As a result, knowledge and awareness are two inseparable concepts. The higher the awareness and knowledge of seafarers, the more successful energy efficiency practices will be. If the seafarers have received adequate training in energy efficiency, have understood the importance of the issue, and have become aware of it, they will always pay attention to energy efficiency in their daily work on the ship and will be able to follow the company's planning to the letter. If these conditions are not met, there will be a difference between planning and implementation. Jaffe \& Stavins (1994) defined this difference as the "energy efficiency gap". The reason why planning cannot be implemented as desired is due to various "barriers" (Backlund, Thollander, Palm, \& Ottosson, 2012). "The concept of barrier can be used to explain the difference between a hypothetical potential and what is actually observed" (Johnson \& Andersson, 2016).

Eight years have passed since the enactment of IMO'S ship energy efficiency regulations. During this time, the maritime sector has worked with all its stakeholders to comply with these regulations. In the early years of regulations, many shipping companies encountered various barriers when implementing these regulations. One of these barriers has been the lack of awareness and knowledge of seafarers about energy efficiency practices (Banks et al., 2012; Jensen et al., 2018; Dewan, Yaakob, \& Suzana, 2018). In the studies conducted on the awareness and knowledge of seafarers in the early years of energy efficiency applica- 
tions, it was stated that the awareness and knowledge of seafarers on energy efficiency on ships were not at the desired level and this level could be increased with training (Banks et al., 2012).

This elapsed eight-year period provided a time for the system to mature. Has this period been beneficial for seafarers to increase their awareness and knowledge about energy efficiency? It is considered that determining the current awareness and knowledge levels of seafarers on energy efficiency will be beneficial for maritime transportation companies. In addition, it is considered important to evaluate the company's energy efficiency practices from the perception of seafarers. Because companies will have the opportunity to evaluate their energy efficiency practices from the perception of seafarers. The evaluation can be useful in the studies that companies will carry out regarding the awareness and knowledge of seafarers. Considering these issues, determining the awareness and knowledge levels of seafarers on energy efficiency on ships and evaluating energy efficiency practices in maritime transportation companies from the perception of seafarers was chosen as the aim of the study. The study will provide information about awareness and knowledge of the energy efficiency of seafarers and from the perception of seafarers the energy efficiency practices of companies. It will thus help fill the gap in research examining energy efficiency practices in ships and companies.

The study is structured as follows: Chapter 2: Literature review, Chapter 3: Material and Methods, Chapter 4: Results, Chapter 5: Discussion and Further Research, Chapter 6: Conclusion.

\section{Literature Review}

IMO initiatives that entered into force in 2013 have aimed to reduce greenhouse gases, especially carbon dioxide, which is the most abundant in the atmosphere and its amount varies with human activities (Banks et al., 2012). In this past eight-year period, the maritime transportation sector has worked on a company basis to adapt to new initiatives and to increase energy efficiency on ships. It has been aimed to reduce the amount of carbon dioxide emitted into the atmosphere by reducing the fuel consumption of the ships with the measures that can be divided into two as technical and operational.

Energy efficiency practices on ships are carried out by seafarers. Achieving the desired benefit from energy efficiency depends on the efforts of seafarers. For this reason, in the years when IMO initiatives for energy efficiency on ships were launched, studies were conducted by some authors to examine seafarers within the scope of energy efficiency on ships. For example, investigating seafarers on operations related to energy efficiency on ships, Banks et al. conducted a survey on seafarers as part of their 2012 study. The aim of the survey was identified as learning the awareness, knowledge, motivation, and opinions of seafarers about carbon emissions and operational changes in ships to reduce carbon emissions, as well as identifying training needs on this issue. At the end of the study, it was determined that most of the seafarers acquired their awareness and knowledge about carbon emissions through newspaper news and television programs, and those who stated that they obtained this information by participating in the training constitute 20 percent. It has been observed that even those who attended the training could not define the course required to focus on this topic. In this context, it has been argued that it is necessary to provide awareness, knowledge, and technical knowledge about best practices for energy efficiency operations and how to apply them to all seafarers through courses. (Banks et al., 2012)

The success of ship energy efficiency applications can be achieved by including the human factor in the process (Kitada \& Ölçer, 2015b). Ships cannot be operated energyefficiently without skilled and knowledgeable seafarers (Johnson, Johansson, \& Andersson, 2014). Knowledgeable and experienced seafarers make the greatest contribution to energy efficiency and emissions reduction on ships (Baldauf et al., 2013). The implementation of ship energy efficiency measures as planned can be achieved by having the awareness and knowledge of seafarers (Viktorelius \& Lundh, 2019; Rasmussen, Lützen, \& Jensen, 2018). Because, no matter how well planned in the company, the insufficient awareness and knowledge of the seafarers may cause the applications on the ship not to be performed as desired. In processes of ship energy efficiency where seafarers are so important, some deficiencies of seafarers can create some barriers to energy efficiency practices. The elimination of barriers will greatly contribute to improving energy efficiency on ships. The lack of knowledge, awareness, and competence of seafarers is a barrier to energy efficiency practices in ships (Jafarzadeh \& Utne, 2014; Dewan et al., 2018).

The elimination of this barrier can be achieved by training seafarers (Dewan et al., 2018). Jafarzadeh \& Utne (2014) stated that in order to overcome barriers, it is necessary to measure the competence of seafarers, train them, repeat the training to maintain the level of education, and update the training with new technological information. Banks et al. (2011) suggested a model course on energy efficiency, stating that the new regulations on energy efficiency on ships will directly affect the working patterns of seafarers and that training should be given in this regard. Rasmussen et al. (2018) argued that seafarers should be trained to gain more energy efficiency skills, as they are the most important link in the system. In their study on energy efficiency with the bridge simulator, Jensen et al. (2018) stated that seafarers can focus on energy efficiency issues by installing technical equipment and raising their awareness. In this way, it has been reported that a fuel saving of 10 percent is achieved in the simulator environment and that the personnel of maritime companies can be trained with the recommended system on energy efficiency. 
It has also been argued in the studies that new technologies such as smart systems that are being used on ships can have a positive effect on awareness and knowledge of energy efficiency by increasing information sharing and cooperation among seafarers. Man et al. (2018) examined the contribution of technology to knowledge sharing among seafarers in his work on the relationships and cooperation between the deck and engine compartments on energy efficiency. At the end of the study, the authors argued that the smart technologies available to the maritime industry on energy efficiency provide a basis for understanding the potential values in collaborative learning, knowledge sharing, and organizational decision-making processes. The authors also stated that the ground created by smart systems, whose use has increased with digitalization, may lead to changes in socio-cultural dimensions among seafarers and these issues should be examined in the future. Technological developments and smart systems installed on ships require seafarers to work in harmony. The success of energy efficiency applications on ships relies on the cooperation of the seafarers (Lützen, Mikkelsen, Jensen, \& Rasmussen, 2017). For this reason, all shipboards must have a high level of awareness and knowledge. It is also essential that seafarers have a common understanding of common critical missions (Kataria, Holder, Praetorius, Baldauf, \& Schróder-Hinrichs, 2015).

In the study, it has been also assessed the knowledge level of seafarers on operational energy efficiency measures. In this context, studies on operational energy efficiency have been examined. Fagerholt et al. (2010) argued that by optimizing the speed of each leg in a voyage planning, fuel consumption and emissions can be reduced, and significant savings can be achieved and proposed a method. Chang \& Chang (2013) established a relationship among ship speed, fuel consumed, and emitted carbon dioxide, and stated that speed reduction reduced fuel consumption and carbon dioxide emissions to a greater extent. Psaraftis \& Kontovas (2013) conducted a study on speed in maritime transportation. In this study, they examined speed models in which speed is among the decision variables and created a taxonomy. At the end of the study, it was determined that ship speed is the most important determinant of economic and environmental sustainability. In their studies in 2014, they developed models that optimize ship speed and made suggestions that could provide a balance for economic and environmental solutions (Psaraftis \& Kontovas, 2014). Chang \& Wang (2014) examined the effects of speed reduction to reduce shipping costs and carbon dioxide emissions and stated that optimum speed reduction is a dynamic process largely dependent on chartering fees and fuel prices. Magirou et al. (2015) conducted a study on the economic speed of ships and produced a model that uses dynamic programming equations different from static Markovian decision processes. Beşikçi et al. (2016a) developed an Artificial Neural Network based decision support system that uses the fuel forecast model to estimate ship fuel consumption.
Thus, it is aimed to estimate ship fuel consumption under various operational conditions. Beşikçi et al. (2016b) conducted a study on operational energy efficiency applications within the scope of SEEMP on ships and prioritized each measure with the Analytic Hierarchy Process. Wang et al. (2018) proposed a dynamic optimization method to optimize ship energy efficiency calculation in line with changing environmental factors and it is predicted that fuel consumption and carbon dioxide emission can be reduced with the proposed method. Adland et al. (2018) stated in their study that periodic hull cleaning provides a considerable reduction in fuel consumption. The studies show that there is great potential for improvements in energy performance, which can be achieved by installing new technologies or changing existing operational applications.When the subject of ship energy efficiency is examined in the literature, it is seen that there are limited studies on the awareness and knowledge of seafarers on energy efficiency, and these studies were carried out in the years when energy efficiency applications in ships began. Since this study determines the current level of awareness and knowledge of seafarers on energy efficiency, it is considered that the study will fill this gap in the literature.

\section{Material and Methods}

\subsection{Data Collection}

Seafarers are responsible to operate the ship, generally distant from shore offices, and are therefore essential to the successful operation of energy efficiency measures affecting fuel consumption. The involvement of seafarers is needed for adapting many operational measures such as the decision for speed optimization or weather routing for energy efficiency (Kitada \& Ölçer, 2015a; Rasmussen et al., 2018; Banks et al., 2012). Due to the critical role of seafarers in daily operational practices, enhancing their energy efficiency awareness and knowledge is important to increase energy efficiency and achieve energy savings onboard a ship. In this study, the survey method was used for data collection. One of the reasons for using a survey is that respondents may feel more comfortable because their individual responses are anonymous and treated as confidential (Transportation Research Board of the National Academies, 2015).

\subsubsection{Survey Objective and Application}

The objectives of the survey were to investigate to determine the level of awareness and knowledge of Turkish ship officers on energy efficiency, to reveal the deficiencies, and to examine energy efficiency practices in their ships and companies. The target group for this questionnaire was Turkish ship officers. Nine large-scale and corporate shipping companies from different fields (tanker, container, bulk cargo, etc.) operating in Turkey were selected to carry out the survey. The study to be done was 
explained by contacting the management of the companies and their assistance was requested in this regard. The internet-based survey link was sent to the officers working on the ships via e-mail by the companies. The sending of the survey by the companies created a corporate perception in the application of the survey and increased participation. The survey was applied to 170 Turkish ship officers and data was collected over an eight-week period from February 02 to April 01, 2017.

\subsubsection{Survey Design}

The survey consists of three parts. Part 1: Personal Information, Part 2: Energy Efficiency Awareness Scale in Ships, Part 3: Marking the levels of the items within the scope of SEEMP. In the survey, firstly, the subject is briefly explained under a title. The names of the participants were not requested in order to answer the questions more sincerely and healthily. Part 1 consists of eight questions aiming to determine the gender, age, education level, the type of ship he/she worked, the department, position on the ship, working time, and whether he/she received training on energy efficiency or not. In Part 2 , it is aimed to determine the awareness level of officers about energy efficiency. With a total of 14 questions in this part, it aims to evaluate the knowledge of officers about SEEMP, EEDI, EEOI and to investigate the level of knowledge about the company's policies on ships. The first five questions aim to measure the level of knowledge, while the remaining nine are questions with multiple answers, where the views of officers are taken, and their awareness levels are highlighted. In Part 3, the level of applications of energy efficiency measures and elements within the scope of SEEMP is detected to identify energy efficiency differences between work as imagined and work as done onboard. In this part, triple Likert Scales were used.

The Likert Scale is a psychometric scale used to measure people's opinions in survey studies. The respondents state whether they agree with an opinion asked to them. They may indicate their state of agreeing or disagreeing fully, as well as partially agreeing with the opinion. The degrees of partially agreeing can be determined by the scale to be formed. (Likert, 1932) Likert Scales were preferred because they are easy to use by the survey participants and prevent confusion arising from misunderstandings.

\subsection{Measures and Statistical Analysis}

Analysis of the obtained survey data was done using the statistics program SPSS 15.0 software and tables were produced in Microsoft Excel. Descriptive statistics were used to present responses of the participants to survey items in order to reveal frequencies, percentages, averages (means) and standard deviations of the survey questions about ship energy efficiency. Because Descriptive Statistics is very useful for defining basically what the data is and what it shows, namely the basic features of the data (Trochim, 2007). In addition, since comparisons of more than one group can be made with it (Stata \& Park, 2005), the One-Way ANOVA test was carried out to find if there were any significant differences between demographic characteristics and knowledge level scores of officers. Since significant results were seen between the groups by ANOVA test, LSD post hoc test (Williams \& Abdi, 2010) was applied in order to make a comparison and determine the two groups from which the difference arises. A p-value less than 0.05 as a significance level is referred for statistical analyses.

\section{Results}

In total, 170 participants (Turkish ship officers) took part in the survey. As seen in Table 1, while $84.7 \%$ of the officers in the study $(\mathrm{N}=170)$ are male and $15.3 \%$ are female. $34.7 \%$ of the officers are $20-25$ years old, $33.5 \%$ are 26-30 years old, $20 \%$ are $31-35$ years old, $11.8 \%$ are 36 years old and above. $92.4 \%$ of the officers graduated with an associate degree and $7.6 \%$ with a bachelor's degree. $54.1 \%$ of the officers work in tankers, $14.7 \%$ in container ships, $22.9 \%$ in dry bulk cargo ships, and $8.2 \%$ in other ships (Ro-Ro, etc.). $65.6 \%$ of the officers work in the deck and $34.4 \%$ in the engine department. $9.4 \%$ of the officers are master, $19.4 \%$ of the officers are the first officer, $34.7 \%$ of the officers are the 2nd or 3rd officer, $8.8 \%$ of the officers are the chief engineer, $6.5 \%$ of the officers are the second engineer, and $21.2 \%$ of the officers are 3rd or 4 th engineers. The total working time of $22.4 \%$ of the officers in the maritime profession is less than 1 year, $24.1 \%$ of them are 1-3 years, $22.4 \%$ of them are $4-6$ years and $31.2 \%$ of them are more than 6 years. $57.6 \%$ of the officers received energy efficiency training in the maritime industry.

Table 2 shows the answers to the five questions, aiming to determine the basic knowledge levels of officers on energy efficiency. Most officers have enough information about the place where energy efficiency regulations are defined $(70.6 \%$ true), the purpose of SEEMP $(71.2 \%$ true), the requirements for having SEEMP on ships ( $54.7 \%$ true), and EEDI mandatory status (58.8\% true). Only the level of knowledge that EEOI is optional was found to be low (39.4\% true). The mean knowledge level of the officers on energy efficiency was found to be $2.95 \pm 1.52$. According to the total score obtained, it can be said that the level of knowledge of the officers about energy efficiency is medium. The survey results showed that the level of knowledge of the participants regarding energy efficiency was lower than expected. In the first question, officers were expected to know that the Regulations for energy efficiency by the IMO are included in MARPOL Annex 6, Chapter 4 . However, close to $30 \%$ of the participants answered this question false, which should be known as basic information. Again, although most participants know the purpose SEEMP (71.2\%) and the date of entry into force (54.75\%), those who do not have knowledge on these issues are too much to be underestimated. It was observed that partici- 
Table 1 Distribution of the participants according to their socio-demographic characteristics

\begin{tabular}{|c|c|c|c|}
\hline Characteristics & Group & $\mathbf{n}$ & $\%$ \\
\hline \multirow{2}{*}{ Gender } & Male & 144 & 84.7 \\
\hline & Female & 26 & 15.3 \\
\hline \multirow{4}{*}{ Age } & $20-25$ & 59 & 34.7 \\
\hline & $26-30$ & 57 & 33.5 \\
\hline & $31-35$ & 34 & 20.0 \\
\hline & 36 and over & 20 & 11.8 \\
\hline \multirow{2}{*}{ Educational level } & Associate degree & 157 & 92.4 \\
\hline & Bachelor's degree & 13 & 7.6 \\
\hline \multirow{4}{*}{ Ship type } & Tanker & 92 & 54.1 \\
\hline & Container & 25 & 14.7 \\
\hline & Dry bulk & 39 & 22.9 \\
\hline & Other & 14 & 8.2 \\
\hline \multirow{2}{*}{ Department } & Deck & 108 & 65.6 \\
\hline & Engine & 62 & 34.4 \\
\hline \multirow{6}{*}{ Position onboard } & Master & 16 & 9.4 \\
\hline & First officer & 33 & 19.4 \\
\hline & 2nd and 3rd officer & 59 & 34.7 \\
\hline & Chief engineer & 15 & 8.8 \\
\hline & Second engineer & 11 & 6.5 \\
\hline & $\begin{array}{c}\text { 3rd and 4th } \\
\text { engineer }\end{array}$ & 36 & 21.2 \\
\hline \multirow{4}{*}{$\begin{array}{l}\text { Total working time } \\
\text { in the maritime } \\
\text { profession }\end{array}$} & Less than one year & 38 & 22.4 \\
\hline & $1-3$ years & 41 & 24.1 \\
\hline & 4-6 years & 38 & 22.4 \\
\hline & More than six year & 53 & 31.2 \\
\hline \multirow{2}{*}{$\begin{array}{l}\text { Energy efficiency } \\
\text { training in the } \\
\text { maritime industry }\end{array}$} & Yes & 98 & 57.6 \\
\hline & No & 72 & 42.4 \\
\hline
\end{tabular}

Source: Authors pants were less aware of the EEDI and the EEOI for new ships. Unfortunately, almost half of the participants were not aware of the EEDI and more than half of the participants were not informed about the EEOI.

Table 3 shows the comparison of the level of knowledge about the energy efficiency of officers by demographic characteristics. In accordance with Table 3, it was determined that total scores of knowledge level about energy efficiency did not differ significantly according to gender, ship type and department served ( $p>0.05$ ). Accordingly, it was observed that the level of knowledge of the officers varied significantly depending on their age, and age affects the knowledge level positively. It has been determined that the total scores of knowledge level about energy efficiency differ according to age groups $(F=6.88$; $p<0.05)$. The level of knowledge about the energy efficiency of officers 31-35 years old and 36 years old and older is significantly higher than that of the officers 20-25 years old and 26-30 years old. It was determined that the total scores of knowledge level about energy efficiency differed according to the educational level. $(\mathrm{t}=-2.84 ; \mathrm{p}<0.05)$. The knowledge level about the energy efficiency of the officers who graduated with the bachelor's degree is significantly higher than the knowledge level of the officers who graduated with the associate degree. It is seen that officers studying for a four-year bachelor's degree have a higher knowledge of energy efficiency than officers with a two-year associate degree education. It was determined that the total scores of knowledge level about energy efficiency differed significantly from the position onboard ( $F=3.95$; $p<0.05)$. The level of knowledge of the officers in the master and 1st officer position is significantly higher than that of the officers in the 2nd and 3rd officer positions. The knowledge level of the officers in the position of chief engineer and 2nd engineer is significantly higher than that of officers in the position of 3rd and 4th engineer. It was determined that the total scores of knowledge level about energy efficiency differed according to the total working time in the

Table 2 Descriptive statistics of officers' knowledge about energy efficiency

\begin{tabular}{|l|c|c|c|c|c|}
\hline \multicolumn{1}{|c|}{ Knowledge about energy efficiency } & \multicolumn{2}{|c|}{ False } & \multicolumn{2}{c|}{ True } & \multirow{2}{*}{$\begin{array}{c}\text { Standard } \\
\text { Mean }\end{array}$} \\
\cline { 3 - 5 } Deviation (SD)
\end{tabular}

\begin{tabular}{|c|c|c|c|c|c|c|}
\cline { 2 - 7 } \multicolumn{1}{c|}{} & Min. & Max. & Mean & SD & Skewness & Kurtosis \\
\hline TOTAL & 0 & 5 & 2.95 & 1.52 & -0.40 & -0.92 \\
\hline
\end{tabular}


Table 3 Comparison of knowledge level scores about energy efficiency by demographic characteristics

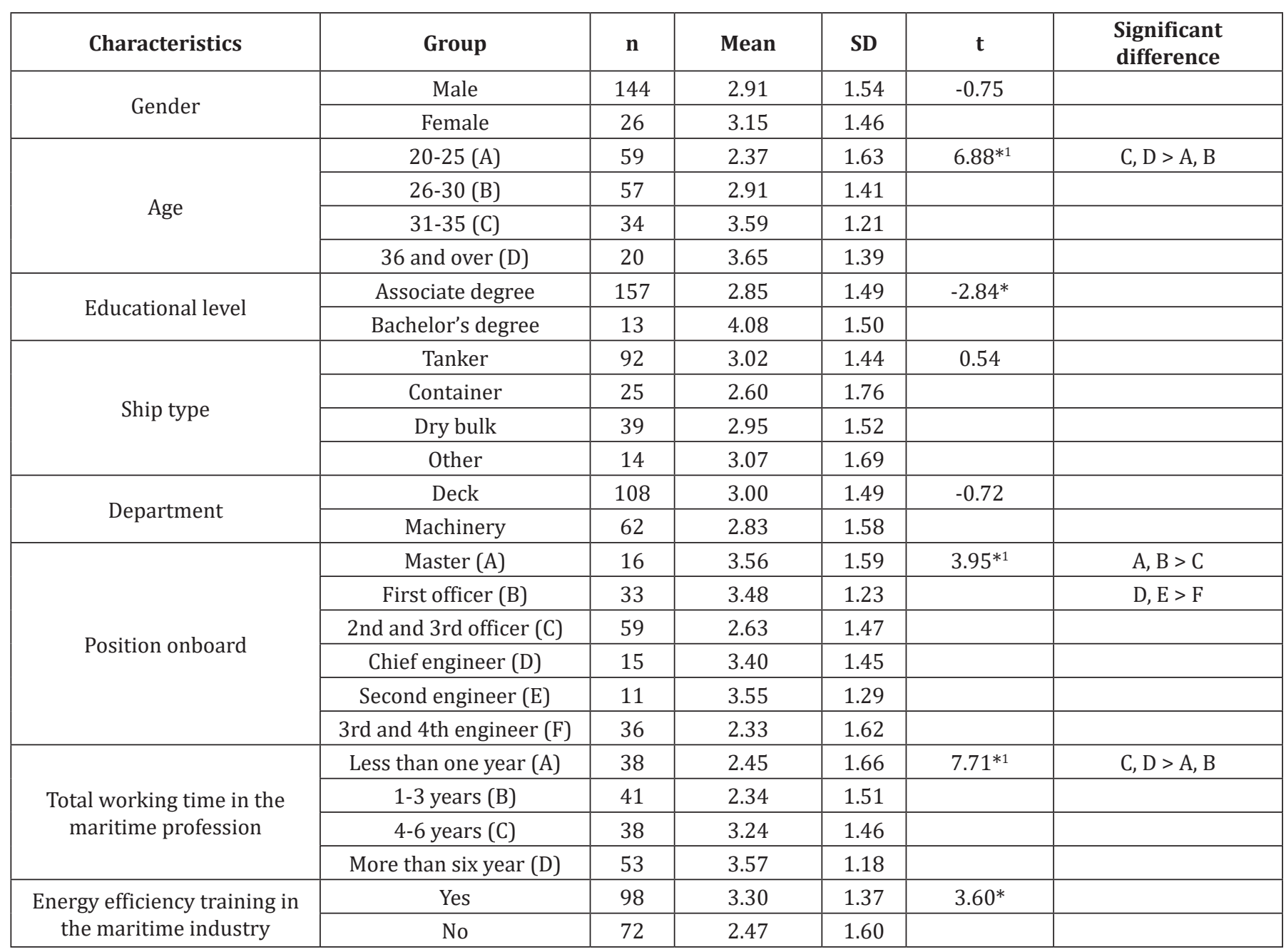

${ }^{*} \mathrm{p}<0.05 ;{ }^{1}$ ANOVA test, F statistics; ${ }^{2}$ LSD post hoc

Source: Authors

maritime profession $(\mathrm{F}=7.71 ; \mathrm{p}<0.05)$. The knowledge level of the officers about the energy efficiency, whose total working time in the maritime sector is 4-6 years and more than 6 years, is significantly higher than the knowledge level of the officers whose total working time in the maritime industry is less than 1 year and 1-3 years. It has been determined that the total scores of knowledge level about energy efficiency differ significantly according to the status of receiving energy efficiency education in the maritime sector $(t=3.60 ; p<0.05)$. The knowledge level of the officers who received energy efficiency training in the maritime sector is significantly higher than the knowledge level of the officers who did not receive energy efficiency training.

In addition, most of the officers (78.8\%) acknowledge that ship energy efficiency practices are an extremely important and fundamental issue. Those who think the practices are not important make up only $12 \%$ of the officers.

Considering the distribution of the opinions regarding the purpose of the company in the development of SEEMP, it is seen that the aims are perceived as reducing gas emissions (22.7\%), providing economic savings (22\%) and complying with international rules (15.3\%), respectively. (Table 4)

Table 4 Distribution of opinions about the purpose of the company in the development of SEEMP

\begin{tabular}{|l|c|c|}
\hline \multicolumn{1}{|c|}{$\begin{array}{c}\text { The purpose of the company in the } \\
\text { development of SEEMP (N=640) }\end{array}$} & f & \% \\
\hline To reduce gas emissions & 145 & 22.7 \\
\hline Economic savings & 141 & 22.0 \\
\hline To comply with the international rules & 98 & 15.3 \\
\hline Ensuring transparency of energy expenditure & 79 & 12.3 \\
\hline Being innovative and pioneering & 63 & 9.8 \\
\hline Increasing trade flexibility (ECA compliance) & 62 & 9.7 \\
\hline $\begin{array}{l}\text { Strengthening the company's position/brand in } \\
\text { the market }\end{array}$ & 52 & 8.1 \\
\hline
\end{tabular}

Source: Authors 
Table 5 shows the responsible person(s)/department for ship energy efficiency. When the responses are evaluated, the rate of respondents as all inspectors in the company is $25.9 \%$, the rate of those who responded as the masters/chief engineer of the ships is $25.3 \%$, and the rate of those who responded as the company's energy department manager/officers is $21.2 \%$. It is understood that most of the maritime companies do not allocate a special department/designated person(s) for energy efficiency management, and energy efficiency management practices are mostly carried out by the companies' all inspectors and shipmaster/chief engineers.

Table 5 Distribution of opinions on who has responsibility for energy management

\begin{tabular}{|l|c|c|}
\hline \multicolumn{1}{|c|}{ Energy management responsibility } & n & \% \\
\hline All inspectors & 44 & 25.9 \\
\hline Ship master/Chief engineer & 43 & 25.3 \\
\hline Energy department manager/Officers & 36 & 21.2 \\
\hline Some selected inspectors & 34 & 20.0 \\
\hline Other & 9 & 5.3 \\
\hline Unanswered & 4 & 2.4 \\
\hline
\end{tabular}

Source: Authors

Considering the distribution of opinions on how energy management data is transferred to the decision unit, $43.5 \%$ of the officers stated that the data related to energy management is transferred to the decision unit by e-mail prepared manually, $24.7 \%$ of the officers stated that the data is transferred automatically in a system and $15.9 \%$ of the officers stated that the data is transferred via e-mail created by the system. It is understood that energy management data is transferred to the company with hand-drawn reports. This step is mostly accomplished by sending a noon/voyage report, which is prepared manually, from the ship to the company via email.

As seen in Table 6, the most common problems when implementing energy management/SEEMP are stated as lack of trained/expert personnel (20\%), incompatibility with existing procedures/processes (15.1\%), and lack of administrative support (13.0\%). This result highlights the need to focus on training to raise energy efficiency awareness.

Considering the distribution of opinions regarding the involvement of the seafarers in determining energy-saving measures, energy saving-measures are mostly determined with the participation of the ship's personnel. $47.6 \%$ of the officers stated that the seafarers were fully involved in the determination of energy-saving measures, $37.6 \%$ stated that the seafarers were asked to give their opinions and $12.9 \%$ stated that they were never included.

In addition, considering the distribution of opinions on how to measure the amount of energy spent for ship
Table 6 Distribution of views on problems encountered while implementing energy management /SEEMP

\begin{tabular}{|l|c|c|}
\hline \multicolumn{1}{|c|}{$\begin{array}{c}\text { Problems when applying energy } \\
\text { management or SEEMP (N=621) }\end{array}$} & f & \% \\
\hline Lack of trained/expert staff & 124 & 20.0 \\
\hline $\begin{array}{l}\text { Failure to comply with existing procedures/ } \\
\text { processes }\end{array}$ & 94 & 15.1 \\
\hline Lack of administrative support & 81 & 13.0 \\
\hline Lack of time for its implementation & 72 & 11.6 \\
\hline Resistance to changes & 62 & 10.0 \\
\hline Other issues of higher importance & 61 & 9.8 \\
\hline Insufficient financial resources & 59 & 9.5 \\
\hline $\begin{array}{l}\text { Implementation guidelines not clear and } \\
\text { understandable }\end{array}$ & 46 & 7.4 \\
\hline Other & 22 & 3.5 \\
\hline
\end{tabular}

Source: Authors

activities in the enterprise, measuring the amount of energy spent on ships by sounding is a general method of application. $58.2 \%$ of the officers stated that the sounder was used to measure the fuel in the ship operations in the enterprise, $35.3 \%$ stated that the fuel meter was used and $4.7 \%$ stated that the energy could not be measured.

Table 7 shows that most of the officers are provided with energy efficiency training from time to time by their companies. However, the rate of officers who have never received training is also high. $34.7 \%$ of the officers stated that awareness-raising training on energy saving was given to the employees from time to time, $30 \%$ of the officers stated that were given periodically, $8.2 \%$ of the officers stated that were given once a year, and $25.9 \%$ of the officers stated that were not provided.

Table 7 Distribution of opinions on providing awareness training on energy-saving to employees

\begin{tabular}{|l|c|c|}
\hline $\begin{array}{c}\text { Providing awareness training to employees } \\
\text { on energy-saving }\end{array}$ & $\mathbf{n}$ & $\mathbf{\%}$ \\
\hline Periodically & 51 & 30.0 \\
\hline From time to time & 59 & 34.7 \\
\hline Once a year & 14 & 8.2 \\
\hline Not provided & 44 & 25.9 \\
\hline Unanswered & 2 & 1.2 \\
\hline
\end{tabular}

Source: Authors

Considering the distribution of opinions about what kind of incentives are given to the seafarers about energy saving, $4.7 \%$ of the officers stated that ship personnel were given a financial reward for energy saving, 10\% of the officers stated that were given a moral reward and $84.1 \%$ of the officers stated that personnel were not encouraged. It is understood that most companies do not have a reward system for energy efficiency. 
Table 8 Distribution of views on the application levels of the measures within the SEEMP

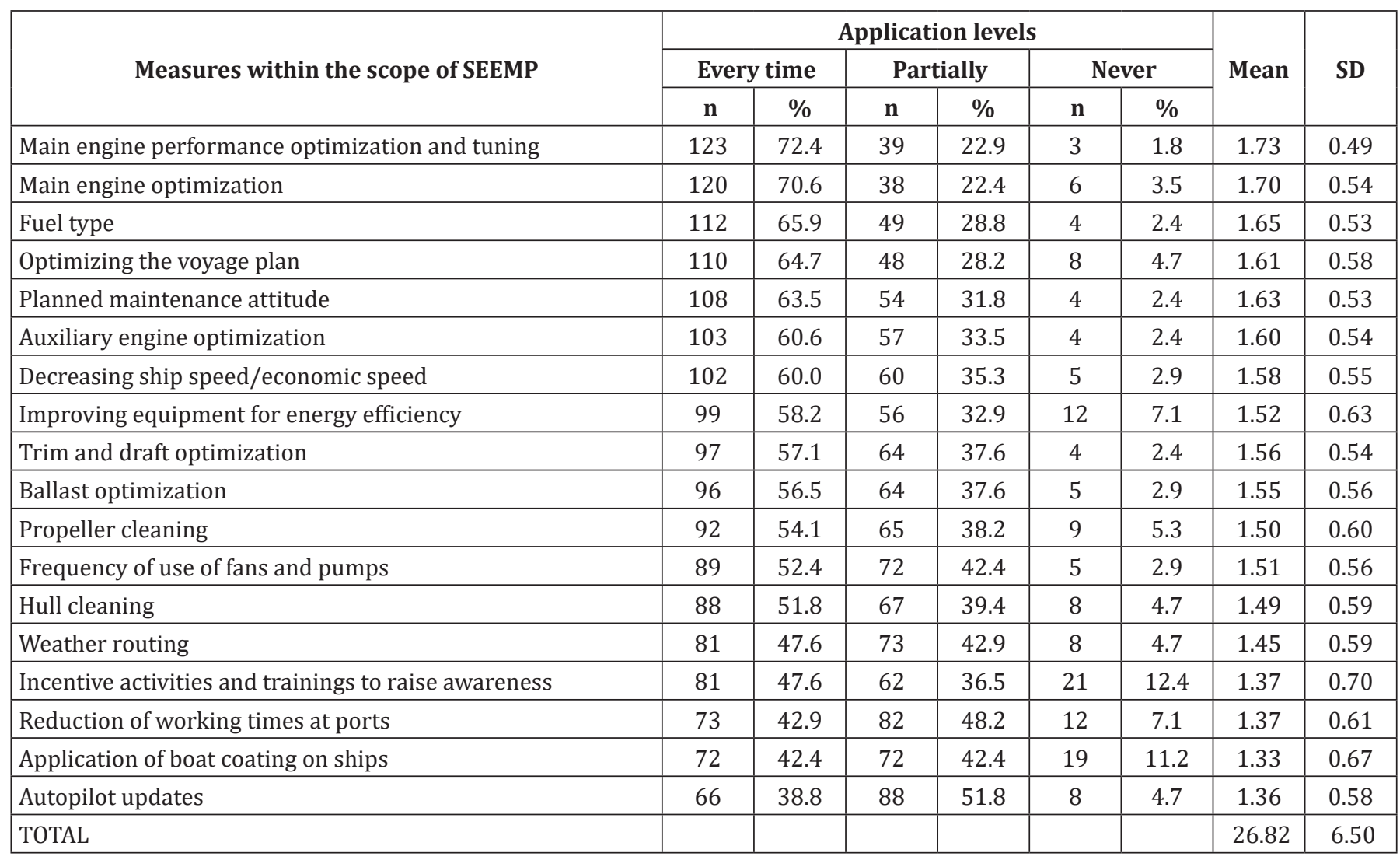

Source: Authors

As seen in Table 8, according to the perception of the officers, the most frequently applied measures of the SEEMP are the main machinery performance optimization and tuning (1.73 \pm 0.49$)$ on ships; main engine optimization $(1.70 \pm 0.54)$, and fuel type $(1.65 \pm 0.53)$. The overall application level of the measures within the scope of SEEMP was found to be $26.82 \pm 6.50$. The obtained value shows that the measures within the scope of SEEMP are implemented at a medium level. Applications cannot be applied in real life at the level they are written in theory. This shows that there is still a significant difference between what is taught on energy efficiency and what is applied on ships. This result supports the prediction that there are differences between real practices and theory, which is one of the main objectives of the study.

\section{Discussion and Further Research}

Fuel costs and increases in greenhouse gas emissions have raised the importance of energy efficiency issues in shipping. Energy efficiency regulations have been introduced by IMO under the headings of SEEMP, EEDI, and EEOI. Within the scope of these regulations, it is aimed to provide energy efficiency by determining a specific management plan for each ship, building more suitable structures by examining the design contents, and examining the results under an operational indicator.
There are many options that can be applied to increase energy efficiency in ships. Even though these options are determined and published internationally and made compulsory to be applied onboard by companies, they are not always effectively implemented due to the lack of knowledge and awareness of personnel onboard or in the company, causing energy efficiency barriers. Despite technological innovation and strict policies in energy efficiency in shipping, there still remains a human element gap between the maritime energy efficiency expectation and implementation. It is therefore important to discuss and analyze and the role of the human element within energy management implementations in the interest of efficient and environmental shipping. For this reason, awareness, qualifications and features of the seafarers are the critical parameters to implement ship operations in energy-efficient ways.

For the reasons stated above, the aim of the study is to determine the awareness and knowledge levels of seafarers on energy efficiency on ships and to evaluate energy efficiency practices in maritime transportation companies from the perception of the seafarers. A survey was conducted to obtain this information.

Knowledge management literature in energy efficiency highlighted the importance of awareness, knowledge, motivation and ideas of the seafarer in practices and implementations (Banks et al., 2012). Energy efficiency awareness 
and knowledge includes not only the energy management standards, such as SEEMP, but also covers management practices and knowledge transfer within the organization in the context of energy efficiency onboard ships (Parent, Roy, \& St-Jacques, 2007). Man et al. (2018) applied research to seafarers (ship engineers and navigational officers) in order to investigate gaps in the energy efficiency practices and recognized that knowledge transfer for a mutual understanding onboard ships is important for saving fuel.

Our study has a limitation to the survey in terms of detecting awareness and knowledge of seafarers which need to be improved in the future. In the survey, the knowledge assessment for seafarers is based on solely the internationally compulsory standards published by IMO, but it also includes questions about practice and engagement level of knowledge such as daily ship operations and knowledge sharing- interaction between and within the seafarers how to save fuel consumption. In the survey, the knowledge of seafarers was investigated in general regardless of their department served but not considered the tailored points to understand their knowledge status in practice depending on the department served. However, the engine and deck departments come with various abilities, responsibilities, and roles (Man et al., 2018) While deck officers are in charge of safe and efficient sailing, engines and other mechanical systems are in control of engineers (Dokkum, 2013). Therefore, it is meaningful to explore the knowledge level by taking into consideration of their operation areas onboard a ship and the design of the survey needs further improvement in related scope in the future. Lastly, the analysis and methods used in this study could also be expanded, particularly using more advanced statistical techniques and methods. In this study, mainly descriptive analysis was applied to reveal the level of awareness and knowledge of the seafarers on energy efficiency and to identify the attitudes, behavior, and policies of companies towards the implementation of energy efficiency measures. In addition, it was also used some advanced statistical methods such as the ANOVA test to assess the relationship between knowledge level scores and demographic characteristics. However, the context and design of the survey could be modified to enable more advanced analysis in the future.

Our main focuses in this paper are on measuring the awareness and knowledge level of seafarers and the perceptions of the seafarers on energy efficiency applications of their shipping companies. Our survey questions were organized according to basic energy management standards, company implementation procedures as well as attitudes towards a list of operational fuel-saving measures identified from the Ship Energy Efficiency Management Plan (SEEMP).

The study revealed that energy-saving applications are perceived as important by seafarers, even if they do not have enough knowledge and training on energy efficiency. The research highlighted that there is a lack of enough theoretical knowledge on IMO standards. Seafarers need to be equipped with satisfactory knowledge for not only standard-based information but also practical knowledge on the selected technologies or measures. For instance, for trim optimization, the seafarers must be familiar with weight distributions with exact precision as well as the optimization tool (Kitada \& Ölçer, 2015a). Some studies also showed that seafarers have insufficient knowledge (Banks et al., 2012; Viktorelius \& Lundh, 2019) which result in a communication issue relating to fuel-saving activities (Dewan et al., 2018; Rasmussen et al., 2018; Johnson et al., 2014) defined as a barrier to ship energy efficiency (Johnson et al., 2014).

Our study also focused on training issues. According to our research, one of the major problems with SEEMP energy efficiency applications relates to the education and training of seafarers. This result is in line with the results of the study of Banks et al. (2012). Their study also revealed the gaps in existing seafarer education and training systems in terms of energy efficiency. Johnson et al. (2014) and Poulsen \& Johnson, (2016) stated in their studies that increased awareness and knowledge of individuals is possible through training on energy efficiency. According to Endsley (1995), training is one of the most important elements in the decision-making process, and lack of knowledge resulting from lack of training can lead to the failure of decisions to respond to problems (Hansen, Rasmussen, \& Lützen, 2020). The lack of training negatively affects the effects of practices such as monitoring systems (Viktorelius \& Lundh, 2016) and is mentioned as a barrier in a number of other researches (DNV GL, 2015; Faber et al., 2011; Jensen et al., 2018; Poulsen, 2012) Increasing awareness and providing the seafarers with the required training are critical components. Both seafarers and shore staff must be trained in order to save fuel. Shipping companies should provide additional training related to energy efficiency especially cover how to use SEEMP and daily fuel-saving operations for seafarers.

The attitudes of shipping companies towards energy efficiency are likely to be insufficient even shore staffs have an important role in analyzing data, operational decision making, and evaluating fuel-saving measures. Because, maritime companies do not allocate a special department/designated person(s) for energy efficiency management, and energy efficiency management practices are mostly carried out by all inspectors and shipmasters/chief engineers of the companies. Clear dedication of responsibility with a person/department employed especially with energy management is of great importance to oversee implementation of measures for sustaining results over time.

The shipping company/organization has an impact on the seafarers by promoting and sharing the vision and strategies of companies for energy saving (Kitada \& Ölçer, $2015 b)$. This study shows that energy-saving measures are mostly determined with the involvement of the ship's personnel which is the desired outcome. To make the SEEMP useful as a dynamic and practical tool which is also in- 
tended by IMO, participation of the seafarers in identifying and meeting goals and objectives influencing the decisionmaking process has great importance in energy-saving activities (Hansen et al., 2020). Participation of shore personnel and the seafarers is critical in order to achieve the goals. The goals are to raise awareness and dedication to specific measures, emphasizing the importance of involving the seafarers as well as shore staff. When implementing the SEEMP, the IMO suggests engaging personnel on land and at sea.

There is a still lack of investment in automation for energy efficiency practices such as transferring energy-related data to the decision units and measuring the amount of energy spent on ships by manual sounding. Seafarers are already overworked, both while at sea and ashore, and should not be burdened with the task of collecting energy data and delivering it to the companies at noon. In addition, manual applications may involve errors (Pedersen \& Larsen, 2009; Safaei et al., 2018). The mistake made in this regard also deflects the follow-up evaluation of the results of energy efficiency applications. Some of the data that make up the noon/voyage report consist of average values such as the average ship speed recorded since the previous noon report, while others consisted of observations during the report, such as instantaneous wind speed. This makes it difficult to analyze the relationship between average and instantaneous data. For this reason, ship companies should ensure to install an energy-monitoring system with auto logging and an automatic information system (i.e., ship cloud) which does not necessitate any action on the part of the sender (Poulsen \& Sornn-Friese, 2015).

Shipping companies should also consider award systems for energy efficiency. There are some small liner shipping companies that already have adapted energy saving award competitions, where the best-performing seafarers are honored (Poulsen \& Sornn-Friese, 2015). The award has positive consequences for the perception and performance of employees. The effectiveness of human resources management in companies increases the productivity of employees and leads to better financial results (Delaney \& Huselid, 1996; Huselid, Jackson, \& Schuler, 1997) and also contributes to maintaining competitive advantage (Pfeffer, 1995). Nowadays, the personnel of the ships that perform best in energy saving should be awarded by maritime companies (Mitroussi \& Notteboom, 2015). One of the important outputs of this study is the identification of the differences between planned SEEMP applications and those implemented onboard. The study demonstrates that there are differences between the planned measures and their real practice achievement onboard. This gap might be a result of a lack of understanding of operational practice, which was observed by Viktorelius \& Lundh (2019) and Hansen et al. (2020). The energy efficiency gap has been defined by Jaffe \& Stavins (1994) as a difference between the calculated optimum energy use and how much it is actually used. Mitroussi \& Notteboom (2015) also mentioned that there is a gap between work as imagined in SEEMP and work as done onboard. To ensure the transformation of theory put into practice and use the SEEMP as a practical tool, all stakeholders including the energy managers/inspectors in the shipping company, the charterer, and port officers should be included in determining specific energy efficiency goals of SEEMP with effective communication. In this way, this would aid ship-specific management of conflicting objectives such as weather routing, trim optimization, etc. more effectively and make it simpler for the seafarer to be aware of how to behave in difficult conditions. In addition, the seafarers exemplify shipboard operations so the company must pay attention to involve seafarers and use their feedback in developing the content of the SEEMP for a particular ship. This would give the shipping company valuable insight into day-to-day operations and ensure it set more meaningful objectives (Hansen et al. (2020).

\section{Conclusion}

Today, due to economic and environmental problems, reducing the fuel consumption of ships by establishing energy efficiency management has become a fundamental requirement. Energy efficiency in ships can be achieved through operational issues stipulated by regulations and enforcement. But for these operational implementations to be carried out in an ideal way, the awareness, knowledge skills, and motivation factors should be considered. In this study, the awareness and knowledge level of seafarers on energy efficiency was evaluated by using a survey method. This study aims to determine the awareness and knowledge levels of seafarers on energy efficiency on ships and to evaluate energy efficiency practices in maritime transportation companies from the perception of the seafarers.

According to the results of the study, seafarers do not receive adequate training on energy efficiency, but they think the issue is important, even if they do not have enough knowledge on the subject. Based on this, it can be said that company awareness about energy efficiency is not mature enough. In addition, it was observed that the basic knowledge levels of the seafarers regarding energy efficiency were lower than expected. The distribution of knowledge level scores of seafarers according to demographic characteristics shows that the older seafarers, those with higher working time onboard, higher rank within the hierarchical structure of the ship, those working in the management position onboard, and/or those who have bachelor's degree education have advanced level of knowledge on energy saving. This situation is thought to arise due to the increase in the working time of the ship due to the increase in the age of the seafarers and in relation to this, the increase in the work experience and the in-service training they receive. In addition, it is evaluated that management level courses at Maritime Faculties have a great contribution to the awareness and knowledge of seafarers positively. 
This study shows that many shipping companies neither have separate energy management departments nor specially designated persons on the implementation of energy-saving measures. Considering the importance of the energy efficiency issue, it would be beneficial for companies to manage this system with a separate department and designated person(s). In addition, this study recommends establishing a system that can transfer energy management information from ships to the decision-making units automatically without human intervention as manual data includes variations and errors.

It seems that there is still a significant gap between theoretical planning on energy efficiency and what is applied onboard. In order to close this gap, it is considered that the awareness and knowledge levels of seafarers should be increased through energy efficiency training. The study showed that there is a need to support seafarers to have training on energy efficiency. Within the scope of in-house training, it will be beneficial to provide energy efficiency courses to seafarers within the company. In addition, practices such as involving seafarers in ship energy efficiency decision processes and supporting the implementation process with a reward system are defined as the use of SEEMP as a dynamic tool. Using SEEMP as a dynamic tool will increase the awareness, knowledge, sense of responsibility, and motivation of the seafarers.

Ship energy efficiency is a complex issue and does not only depend on the applications of the seafarers. It requires the participation of all parties including the authorities, ship owners and charters, etc. For this reason, there is a need for further research by collecting data from these parties to understand the whole ship's energy management system by collecting data from these parties. In future research, it may be interesting to identify examples of good practices in energy efficiency and to investigate what factors are required for success in ship energy efficiency. Another interesting issue may be to explore how energy efficiency culture can be improved. In addition, with the acceleration of digital transformation in recent years, the increasingly used smart systems on ships have begun to shape the way seafarers work on the ship in many issues. In the process up to the autonomous ships that will be used soon, the systems currently used on ships will also become more digital. This wave of digitization will inevitably lead to changes in the awareness and knowledge of seafarers. In future research, it is beneficial to examine the impact of digital transformation on seafarers in ship energy efficiency applications.

Funding: The research presented in the manuscript did not receive any external funding.

Acknowledgements: This work is supported by Maritime Education for Energy Efficiency (MarEd) Project funded by the European Commission under the framework of Erasmus+ KA2 Cooperation for Innovation and the Exchange of Good Practices, KA202 Strategic Partnership for vocational education, and training. (Grant Number: 2018-1-TR01-KA202-058717).

Author Contributions: Research, Elif Bal Beşikçi, Murat Selçuk Solmaz, Irena Jurdana; Writing, Elif Bal Beşikçi, Murat Selçuk Solmaz; Verification/Mathematical harmonization, Elif Bal Beșikçi.

\section{References}

[1] Adland, R., Cariou, P., Jia, H., \& Wolff, F. C. (2018). The energy efficiency effects of periodic ship hull cleaning. Journal of Cleaner Production, 178, 1-13. https://doi.org/10.1016/j. jclepro.2017.12.247.

[2] Backlund, S., Thollander, P., Palm, J., \& Ottosson, M. (2012). Extending the energy efficiency gap. Energy Policy, 51, 392396. https://doi.org/10.1016/j.enpol.2012.08.042.

[3] Baldauf, M., Baumler, R., Ölçer, A., Nakazawa, T., Benedict, K., Fischer, S., \& Schaub, M. (2013). Energy-efficient Ship Operation - Training Requirements and Challenges. TransNav, International Journal on Marine Navigation and Safety of Sea Transportation, 7(2), 283-290. https://doi. org/10.12716/1001.07.02.16.

[4] Banks, C., Lazakis, I., Turan, O., \& Incecik, A. (2011). An approach to education and training of seafearers in low carbon - energy efficiency operations. Proceedings of the Low Carbon Shipping Conference. Retrieved April 7, 2020, from https://www.semanticscholar.org/paper/Anapproach-to-education-and-training-of-seafarers-BanksLazakis/d9da4124798ca74db11e53fbd8f83b6ba7901025.

[5] Banks, C., Turan, O., Incecik, A., Lazakis, I., \& Lu, R. (2012). Seafarers' Current Awareness, Knowledge, Motivation and Ideas towards Low Carbon-Energy Efficient Operations, 4, 93-109. Retrieved May 12, 2021, from https://strathprints. strath.ac.uk/66398/1/Banks_etal_JSOE_2014_Seafarers_ current_awareness_knowledge_motivation.pdf.

[6] Beşikçi, E. B., Arslan, O., Turan, O., \& Ölçer, A. I. (2016a). An artificial neural network based decision support system for energy efficient ship operations. Computers and Operations Research, 66, 393-401. https://doi.org/10.1016/j.cor.2015. 04.004 .

[7] Beşikçi, E. B., Kececi, T., Arslan, O., \& Turan, O. (2016b). An application of fuzzy-AHP to ship operational energy efficiency measures. Ocean Engineering, 121, 392-402. https://doi.org/10.1016/j.oceaneng.2016.05.031.

[8] Chang, C. C., \& Chang, C. H. (2013). Energy conservation for international dry bulk carriers via vessel speed reduction. Energy Policy, 59, 710-715. https://doi.org/10.1016/j. enpol.2013.04.025.

[9] Chang, C. C., \& Wang, C. M. (2014). Evaluating the effects of speed reduce for shipping costs and $\mathrm{CO}_{2}$ emission. Transportation Research Part D: Transport and Environment, 31, 110-115. https://doi.org/10.1016/j.trd. 2014.05.020.

[10] Delaney, J. T., \& Huselid, M. A. (1996). The impact of human resource management practices on perceptions of organizational performance. Academy of Management Journal, 39(4), 949-969. Retrieved May 12, 2021, from https://www.researchgate.net/publication/247900192_ The_Impact_of_Human_Resource_Practices_on_ Perceptions_Organizational_Performance. 
[11] Dewan, M. H., Yaakob, O., \& Suzana, A. (2018). Barriers for adoption of energy efficiency operational measures in shipping industry. WMU Journal of Maritime Affairs, 17(2), 169-193. https://doi.org/10.1007/s13437-018-0138-3.

[12] DNV GL, (2015). Energy Efficient Operation - What Really Matters, (2015). Energy Management Study. Retrieved April 5, 2019, from https://pdf4pro.com/view/energy-efficientoperation-what-matters-d9580.html.

[13] Dokkum, Van, K. (2013). Ship Knowledge (8ed). Dokmar Maritime Publishers BV, Enkhuizen, The Netherlands.

[14] Endsley, M. R. (1995). Toward a theory of situation awareness in dynamic systems. Human Factors, 37(1), 32-64. https://doi.org/10.1518/001872095779049543.

[15] European Environment Agency. (2013). The impact of international shipping on European air quality and climate forcing. https://doi.org/10.2800/75763.

[16] Faber, J., Behrends, B., Nelissen, D. (2011). Analysis of GHG Marginal Abatement Cost Curves. Publication number 11.7410.21. Delft, CE Delft. Retrieved March 23, 2020, from https://cedelft.eu/en/publications/1155/analysis-of-ghgmarginal-abatement-cost-curves.

[17] Fagerholt, K., Laporte, G., \& Norstad, I. (2010). Reducing fuel emissions by optimizing speed on shipping routes. Journal of the Operational Research Society, 61(3), 523-529. https://doi.org/10.1057/jors.2009.77.

[18] Hansen, E. K., Rasmussen, H. B., \& Lützen, M. (2020). Making shipping more carbon-friendly? Exploring ship energy efficiency management plans in legislation and practice. Energy Research and Social Science, 65(February), 101459. https://doi.org/10.1016/j.erss.2020.101459.

[19] Huselid, M. A., Jackson, S. E., \& Schuler, R. S. (1997). Technical and strategic human resource management effectiveness as determinants of firm performance. Academy of Management Journal, 40(1), 171-188. Retrieved May 10, 2021, from https://www.researchgate. net/publication/244505347_Technical_and_Strategic_ Human_Resource_Management_Effectiveness_as_ Determinants_of_Firm_Performance.

[20] International Maritime Organization [IMO]. (2015). Third IMO GHG Study 2014. International Maritime Organization (IMO), London UK, 2014 report. Retrieved September 25, 2020, from https://www.imo.org/en/OurWork/ Environment/Pages/Greenhouse-Gas-Studies-2014.aspx.

[21] IMO. (2018). Resolution MEPC.304(72), Initial IMO Strategy on Reduction of GHG Emission from Ships. International Maritime Organization (IMO), London, UK. Retrieved September 25, 2020, from https://wwwcdn.imo.org/ localresources / en/KnowledgeCentre/IndexofIMO Resolutions/MEPCDocuments/MEPC.304(72).pdf.

[22] IMO. (2020a). Energy Efficiency Measures. Retrieved November 01, 2021, from https://www.imo.org/en/ OurWork/Environment/Pages/Technical-and-OperationalMeasures.aspx.

[23] IMO. (2020b). IMO Train the Trainer (TTT) Course on Energy Efficient Ship Operation. Retrieved November 01, 2021 , from https://www.imo.org/en/OurWork/ Environment/Pages/IMO-Train-the-Trainer-Course.aspx.

[24] Jafarzadeh, S., \& Utne, I. B. (2014). A framework to bridge the energy efficiency gap in shipping. Energy, 69(May), 603-612. https://doi.org/10.1016/j.energy.2014.03.056.

[25] Jaffe, A. B., \& Stavins, R. N. (1994). The energy-efficient gap: What does it mean? What does it mean? Energy Policy,
22(10), 804-810. Retrieved June 12, 2021, from https:// www.sciencedirect.com/science/article/abs/pii / 0301421594901384.

[26] Jensen, S., Lützen, M., Mikkelsen, L. L., Rasmussen, H. B., Pedersen, P. V., \& Schamby, P. (2018). Energy-efficient operational training in a ship bridge simulator. Journal of Cleaner Production, 171, 175-183. https://doi.org/ 10.1016/j.jclepro.2017.10.026

[27] Johnson, H., \& Andersson, K. (2016). Barriers to energy efficiency in shipping. WMU Journal of Maritime Affairs, 15(1), 79-96. https://doi.org/10.1007/s13437-014-0071-z.

[28] Johnson, H., Johansson, M., \& Andersson, K. (2014). Barriers to improving energy efficiency in short sea shipping: An action research case study. Journal of Cleaner Production, 66, 317-327. https://doi.org/10.1016/j.jclepro.2013.10.046.

[29] Kataria, A., Holder, E., Praetorius, G., Baldauf, M., \& SchróderHinrichs, J.-U. (2015). Exploring Bridge-Engine Control Room Collaborative Team Communication. TransNav, the International Journal on Marine Navigation and Safety of Sea Transportation, 9(2), 169-176. https://doi.org/ 10.12716/1001.09.02.02.

[30] Kitada, M., \& Ölçer, A. (2015a). A contemporary outlook on human element in energy efficient seaborne transportation. Proceedings - 16th Annual General Assembly and Conference of the International Association of Maritime Universities, IAMU AGA 2015, 46(0), 149-154. Retrieved May 12, 2021, from https://www.researchgate.net/ publication/283485173_A_Contemporary_Outlook_on_ Human_Element_in_Energy_Efficient_Seaborne_ Transportation.

[31] Kitada, M., \& Ölçer, A. (2015b). Managing people and technology: The challenges in CSR and energy efficient shipping. Research in Transportation Business and Management, 17, 36-40. https://doi.org/10.1016/j.rtbm. 2015.10.002.

[32] Li, X., Sun, B., Guo, C., Du, W., \& Li, Y. (2020). Speed optimization of a container ship on a given route considering voluntary speed loss and emissions. Applied Ocean Research, 94(March 2019), 101995. https://doi. org/10.1016/j.apor.2019.101995.

[33] Likert, R. A. (1932). Technique for the measurement of attitudes. Archives of Psychology, 140: 1-55. Retrieved July 23, 2021, from https://psycnet.apa.org/record/1933-01885-001.

[34] Lützen, M., Mikkelsen, L. L., Jensen, S., \& Rasmussen, H. B. (2017). Energy efficiency of working vessels - A framework. Journal of Cleaner Production, 143, 90-99. https://doi. org/10.1016/j.jclepro.2016.12.146.

[35] Magirou, E. F., Psaraftis, H. N., \& Bouritas, T. (2015). The economic speed of an oceangoing vessel in a dynamic setting. Transportation Research Part B: Methodological, 76, 48-67. https://doi.org/10.1016/j.trb.2015.03.001.

[36] Man, Y., Lundh, M., \& MacKinnon, S. (2018). Maritime Energy Efficiency in a Sociotechnical System: A Collaborative Learning Synergy via Mediating Technologies. TransNav, the International Journal on Marine Navigation and Safety of Sea Transportation, 12(2), 239-250. https:// doi.org/10.12716/1001.12.02.03.

[37] Mitroussi, K., \& Notteboom, T. (2015). Getting the work done: motivation needs and processes for seafarers and dock workers. WMU Journal of Maritime Affairs, 14(2), 247-265. https://doi.org/10.1007/s13437-014-0064-y. 
[38] Parent, R., Roy, M., \& St-Jacques, D. (2007). A systems-based dynamic knowledge transfer capacity model. Journal of Knowledge Management, 11(6), 81-93. https://doi. org/10.1108/13673270710832181.

[39] Pedersen, B. P., \& Larsen, J. (2009). Prediction of Full-Scale Propulsion Power using Artificial Neural Networks. In Notes and Queries (Vol. s1-VI, pp. 537-550). Retrieved November 01, 2021, from, from https://www. semanticscholar.org/paper/Prediction-of-Full-ScalePropulsion-Power-using-Pedersen-Larsen/470b0303f1616 0b521d36eac93f2b564428602f0.

[40] Pfeffer, J. (1995). Producing sustainable competitive advantage through the effective management of people. Academy of Management Perspectives, 9(1), 55-69. https://doi.org/10.5465/ame.1995.9503133495.

[41] Poulsen, R. T., (2012). Emissions and Energy Efficiency: The Twin Challenges for Shipping. Mercator, (March-June), 447 454. Retrieved May 12, 2021, from https://research.cbs.dk/ en/publications/emissions-and-energy-efficiency-thetwin-challenges-for-shipping.

[42] Poulsen, R. T., \& Sornn-Friese, H. (2015). Achieving energy efficient ship operations under third party management: How do ship management models influence energy efficiency? Research in Transportation Business \& Management 17 (2015) 41-52. Retrieved April 25, 2021, from https://research.cbs.dk/en/publications/achievingenergy-efficient-ship-operations-under-third-party-mana.

[43] Poulsen, R. T., \& Johnson, H. (2016). The logic of business vs. the logic of energy management practice: Understanding the choices and effects of energy consumption monitoring systems in shipping companies. Journal of Cleaner Production, 112, 3785-3797. https://doi.org/10.1016/j. jclepro.2015.08.032.

[44] Psaraftis, H. N., \& Kontovas, C. A. (2013). Speed models for energy-efficient maritime transportation: A taxonomy and survey. Transportation Research Part C: Emerging Technologies, 26, 331-351. https://doi.org/10.1016/j.trc. 2012.09.012.

[45] Psaraftis, H. N., \& Kontovas, C. A. (2014). Ship speed optimization: Concepts, models and combined speed-routing scenarios. Transportation Research Part C: Emerging Technologies, 44, 52-69. https://doi.org/10.1016/j.trc.2014. 03.001.

[46] Rasmussen, H. B., Lützen, M., \& Jensen, S. (2018). Energy efficiency at sea: Knowledge, communication, and situational awareness at offshore oil supply and wind turbine vessels. Energy Research and Social Science, 44(November 2017), 50-60. https://doi.org/10.1016/j. erss.2018.04.039.

[47] Rehmatulla, N., \& Smith, T. (2015). Barriers to energy efficiency in shipping: A triangulated approach to investigate the principal agent problem. Energy Policy, 84, 44-57. https://doi.org/10.1016/j.enpol.2015.04.019.

[48] Safaei, A. A., Ghassemi, H., \& Ghiasi, M. (2018). Correcting and enriching vessel's noon report data using statistical and data mining methods. European Transport - Trasporti Europei, (67). Retrieved May 12, 2021, from https://www. researchgate.net/publication/324219795_Correcting_and_ enriching_vessel's_noon_report_data_using_statistical_and_ data_mining_methods.

[49] Stata, A. U., \& Park, H. M. (2005). Comparing Group Means: The T-test and One-way ANOVA Using STATA, SAS, and SPSS. The Trustees of Indiana University, 1-57. Retrieved May 22, 2021, from https://citeseerx.ist.psu.edu/viewdoc/downloa d?doi=10.1.1.601.6459\&rep=rep1\&type=pdf.

[50] Transportation Research Board of the National Academies (2015). Improving Safety Culture in Public Transportation. Transit Cooperative Research Program (TCRP) Report 174. Retrieved November 01, 2021, from https://citeseerx.ist.psu.edu/viewdoc/download?doi=10.1.1.675.3160\&rep=rep1\&type=pdf.

[51] Trochim W. M. (2007). Research Methods Knowledge Base. Retrieved May 22, 2021, from https://researchgate.net/ publication/243783609_The_Research_Methods_ Knowledge_Base.

[52] UNCTAD. (2020). Review of Maritime Transport. Retrieved May 11, 2021, from https://unctad.org/system/files/ official-document/rmt2020_en.pdf.

[53] Viktorelius, M., Lundh, M. (2016). The role of distributed cognition in ship energy optimization. RINA, Royal Institution of Naval Architects - Energy Efficient Ships 2016: International Conference on Energy Efficient Ships 2016; London; United Kingdom; 23-24 November 2016. 133-140. Retrieved May 11, 2021, from http://lnu.diva-portal.org/ smash/record.jsf?pid=diva2\%3A1455981\&dswid=-9819.

[54] Viktorelius, M., \& Lundh, M. (2019). Energy efficiency at sea: An activity theoretical perspective on operational energy efficiency in maritime transport. Energy Research and Social Science, 52(January), 1-9. https://doi.org/ 10.1016/j.erss.2019.01.021.

[55] Wang, K., Yan, X., Yuan, Y., Jiang, X., Lin, X., \& Negenborn, R. R. (2018). Dynamic optimization of ship energy efficiency considering time-varying environmental factors. Transportation Research Part D: Transport and Environment, 62(May), 685698. https://doi.org/10.1016/j.trd.2018.04.005.

[56] Williams, L. J. , \& Abdi, H. (2010). Fisher's Least Significant Difference (LSD) Test. In Neil Salkind (Ed.), Encyclopedia of Research Design. Thousand Oaks, CA. Retrieved May 22, 2021, from https://www.researchgate.net/profile/LynneWilliams-2/publication/242181775_Fisher\%27s_Least_ S igniflcant_Difierence_LS D_ Test/links / 00463528e752d0f005000000/Fishers-Least-SigniflcantDifierence-LSD-Test.pdf. 